\title{
Sustainable Mobility in Metropolitan Areas
}

\author{
María Eugenia López- Lambas \\ $\mathrm{PhD}$. Associate professor. Universidad Politécnica Madrid (UPM) \\ Research Transport Centre TRANSyT-UPM
}

\begin{abstract}
Transport is one of the four priorities of the EU Thematic Strategy on Urban Environment. Cities concentrate 80\% of European population and transport is a key element for their economic vitality. However it also produces pollution, noise, global warming, congestion, etc.

Some cities have faced the problem- particularly aggravated by this relatively new phenomenon known as urban sprawl, perfectly distinguishable in new housing developments perfectly unsustainable-, through integrated strategies which takes account of the interrelations among land use patterns, transport supply and, last but not least, the role of the different modes of transport, in a sort of co-modality that includes walking and cycling. Sustainable Urban Transport Plan for cities or Company Management Plans for big industries look for those objectives.

This paper presents some experiences around Europe: Holland, Spain, France, UK, etc., and their legislative and policy framework. These good practices show how to combine the right level of provision of infrastructures to attend mobility demand, taking care for quality of life and environmental standards in new urban and business developments. The paper points out the key elements of a mobility plan, its phases, measures and the importance of a well designed public participation procedure.
\end{abstract}

\section{Introduction}

Some facts [1]: 
- Europe is one of the most urbanised continents. Approximately $75 \%$ of its population lives in urban areas; by 2020 , this will be $80 \%$ (EEA).

- EU-27 greenhouse emissions would have fallen (1990-2005) by $14 \%$ instead of $7,9 \%$ (TERM). Short term projections indicate that 2010 greenhouse gas emissions will be the same as in 2005.

- Urban transport contributes to $40 \%$ of transport related CO2 emissions and is responsible for $70 \%$ of emissions of other pollutants arising from road transport.

- The number of road traffic accidents in cities is continuously growing: one in three fatal accidents happens in urban areas.

- According to the World Health Organisation, about 100000 deaths a year could be linked to ambient air pollution in cities in Europe.

- $\quad \mathrm{NO}_{2}$ and $\mathrm{PM}_{10}$ concentrations at selected traffic monitoring stations indicate that cities are at or above European quality air limits.

With this panorama, it is not surprising consider transport as the villain of the movie, guilty of almost every wrong thing regarding environment and, all in all, quality of life. But transport sector may -must- be seen from different perspectives, depending obviously on which side are we. So, from an economic point of view, transport contributes for more than $10 \%$ of the GDP of the European Union, and gives employment to more than 10 million people in the same context. On the other side, as a social cohesion and land integration factor transport means other interesting and by no means insignificant key aspect for economic competitiveness of the different countries, fostering a number of associated activities, such as autopropulsion industry, assets, etc.

This said, transport has a dark but not hidden side, linked to the sustainable development of our societies, focused on one of the three pillars of what we have called "sustainability": the environment, in such a way that being the results positive in social and economic, not the same can be said regarding this third one. In other words: transport, and most of all, urban transport, is one of the main responsible of pollution and climate change, not to mention the high energy consumption, noise, dead and injuries, illness, congestion ${ }^{1}$ [2], etc. In fact, in Spain road traffic congestion counts for around $0,2 \%$ of the GDP [3].

\footnotetext{
${ }^{1}$ Only road traffic congestion amounts to $0,50 \%$ of EU GDP, and business as usual, will increase to $1 \%$ for 2010 (White Paper European Transport Policy for 2010: time to decide (COM (2001) 370 final)
} 
Since the aim of this paper is not to provide detailed information on well known issues -emissions, climate change, etc.,- we will focus on how some cities have faced this problem through integrated strategies which take into account the interrelations among land use patterns, transport supply and the role of the different modes of transport, individual and collective, benefiting from the co-modality promoted by the European Union in one of its most recent documents, the Green Paper: Towards a new culture for urban mobility that, obviously, includes walking and cycling as well [4]

That integrated approach, searching the balanced coordination of land use and mobility, is well expressed through the Local Transport Plans (LTP, United Kingdom), Plans de Déplacements Urbains (PDU, France), Piano de Mobilitá Urbana (PUM, Italy), Planes de Movilidad Urbana Sostenible (PMUS, España), and the generic umbrella for all of them: Sustainable Urban Transport Plans (SUTP) [5]. This apparently tongue twister (PDU, LTP, PUM, PMUS, etc.), has a common set of features through which many cities have proven that, many times, simple solutions are the most effective:

- Covers the whole urban area

- Aims to reduce the negative impacts of transport and tackle the rising volumes of traffic and congestion

- Uses to be linked to national/regional strategies

- Covers all modes of transport

- Includes people and goods

- Modal shift in favour of "soft" and alternatives modes

Furthermore, all those strategies involve the coordination and competent use of the different modes of transport to enhance the shift to more energy efficient transport modes, to reduce transport demand and to foster the implementation of technological measures.

\section{From $P D U$ to PUM and PMUS, going through LTP: the tongue twister of urban mobility}

France. French PDU,s (Plans de Déplacements Urbains) are in the origin of the of the urban mobility planning with sustainability criteria. They are based on three laws, the first one from 1982 (Loi d'Orientation des Transports Intérieurs (LOTI)-Inland Transport Law); the second, from 1996, was environmentally oriented: the Loi sur l'Air et l'Utilisation Rationnelle de l'Energie (LAURE) and make PDU compulsory for cities with more than 100,000 inhabitants. The last one, the Loi relative à la Solidarité et au Renouvellement Urbain (SRU), from 2000, was issued by the Trans- 
port Ministry as the first one, and in the framework of the territorial coherence scheme, obliges to set road safety objectives and to be compatible with the land use planning [6].

PDUS - time horizon, 10 years- are elaborated, passed and implemented by the Public Transport Authority, after a public survey process. Local Authorities inside the performance perimeter of the Transport Authority are responsible for the funding (except for Île de France (Paris). Nowadays, the Regions and Departments fund the plan.

As main results, PDU's have put the urban transport plans on the political agenda and that has been translated into the implementation of a lot of tramways, the construction of exclusive bus lanes, a decisive parking policy), the deep involvement of the stakeholders and the increasing in the number of travel plans, among others important outcomes [7]. Nevertheless, is always difficult to assert to what extent the good effects on urban mobility are only due to PDU's, since population ageing or price of fuel, for instance, can also influence $[8,9]$.

More recently, in France have been also launched the so-called "micro PDU", made of specific proposals around the local PDU, such as areas 30, pedestrianisation, parking schemes, bike lanes, etc. Sometimes, those micro plans realized in green commuter plans or company transport plans, usually through soft measures such as public transport, on foot and bicycle.

United Kingdom. LTPs are landmark documents that require authorities to plan a five year programme for managing transport services within a comprehensive and multi modal strategy to achieve local and national objectives [8], i.e., must be consistent with the national plans and goals, both in transport and other issues. After the five years period, the plan is evaluated by the Local Transport Authorities [10].

The first round of LTPs were launched for the period 2000/05, following the Transport Act issued in year 2000, that gave to the local authorities the competencies to implement those plans and, in order to help the authorities to do so, the Government launched a guide that sets the following objectives: to protect the environment, to improve passengers safety, to promote the sustainable growth of the economy, to provide global accessibility, especially for those without a car and to integrate land use and transport policies [11]

The objectives must be coherent with the national goals

Time horizon: 5 years. One of the key aspects of the LTPs is the existence of a set of indicators to evaluate the outcomes against the objectives. An annual progress report is required as a basis for the national funding that could be increased if the objectives are reached. 
Funding: National Government, if the annual report is positive. Then, the Local Authority can be eligible for $75 \%$ of the investment, plus $25 \%$ depending on the quality evaluation and level of achievement.

A new guide for the second round of plans (2006/2011) has been now launched.

Italy. Italian PUM,s [12] starts in 1996, with a Law from the Public Works Ministry on Urban Traffic Plans for cities with more than 30,000 inhabitants. Then, the law 340/2000 and the National Transport Plan defined the methodology for its implementation. Stricto sensu only the traffic plans are compulsory (i.e, appropriate disciplinary measures are taken), since the mobility plans are responsibility of those cities and regions with more than 100,000 inhabitants which can obtain funds from the National Government (up to $50 \%$ of the investment costs of the measures planed in the PUM).

There are a set of national guidelines for the implementation, even if the region produce its own. These guidelines define a set of indicators to measure the effectiveness of the programme. Anyway, the goal is to integrate the PUM at sectoral level, i.e., with the PUT and with the urban and environmental planning.

Time horizon: 10 years, with a bi-annual review.

Funding: National Government $60 \%$ of the investment (as a maximum), and the rest between municipalities and regions.

Objectives: to satisfy the citizen's mobility needs, reduce pollution, noise, energy consumption and private car use, to increase the road safety, to foster car-pooling and car-sharing as mechanisms to reduce congestion in urban areas.

Spain. The Sustainable Urban Mobility Plans (SUMP) [13] were launched in the framework of a strategic and well defined plan, made up of the Master Plan for Infrastructures and Transport and the Energy Saving and Efficiency Strategy. Apart from that, and with the remarkable exception of the Mobility Law issued by the Catalan Government in 2003, there is not any compulsory rule to implement them.

But in 2006 a guide for the elaboration and implementation of Sustainable Urban Mobility Plans (SUMP) was launched. The guide explains in a clear and accessible way the main characteristics that a plan must have, measures, implementation methodologies, stakeholders, public participation process, good practices, etc. There is national funding foreseen to foster its implementation as well. 
The guide recommends to those municipalities with more than 50,000 inhabitants the adoption of a SUMP, within a time horizon depending on the kind of measures to be implemented, 2 to 8 years.

Regarding the objectives, the guide does not provide a list beyond those that the word "sustainable" suggests: it will depend on each case, since the needs of each city differs from one to another, but recommends to keep the plan within a regional strategy, coordinating both levels: municipal and regional.

\section{Some strategies and measures}

There are four basic policy categories in SUTP: 1) Reducing the need for motorised transport, 2) enhancing modal shift, 3) developing clean and silent transport systems, 4) improving transport efficiency (Sustainable Urban [14].

Very schematically, those are some measures to be implemented by means of a SUTP, grouped by intervention areas [13]:

Traffic management and control (TMC)

Parking management (PM)

Fostering public transport (PT)

Recovery urban quality (UQ)

Mobility management through specific measures (MM)

Improvement mobility for impaired people (MIP)

Urban freight transport (UF)

Integrated mobility and land use policies (MLU)

Environmental quality improvement and energy saving (EQ/ES)

Mobility plans for large companies (MPC)

Safety improvement (SI)

\begin{tabular}{|c|c|c|c|c|c|}
\hline TMC & $\begin{array}{l}\text { Traffic calming, speed } \\
\text { limits } 30 \mathrm{~km} / \mathrm{h} \text {, etc. }\end{array}$ & $\begin{array}{l}\text { Junctions regula- } \\
\text { tion: } \\
\text { bus priority and } \\
\text { trams }\end{array}$ & $\begin{array}{c}\text { Ring roads: only } \\
\text { when connecting routes }\end{array}$ & & \\
\hline $\mathbf{P M}$ & $\begin{array}{c}\text { Blue areas, } \\
\text { more parking spaces }\end{array}$ & Park \& ride & & & \\
\hline PT & $\begin{array}{l}\text { Interchanges } \\
\text { (design, location inte- } \\
\text { gration in the city) }\end{array}$ & $\begin{array}{l}\text { Exclusive lanes, } \\
\text { HOV lanes }\end{array}$ & $\begin{array}{c}\text { Network enlarge- } \\
\text { ment, frequency, fleet } \\
\text { renewal, interlinks, etc. }\end{array}$ & $\begin{array}{c}\text { Integrated } \\
\text { tariff system }\end{array}$ & $\begin{array}{l}\text { New technolo- } \\
\text { gies: information, } \\
\text { ITS, etc. }\end{array}$ \\
\hline UQ & Pedestrian zones & Cycle lanes & Bicycle loans & $\begin{array}{l}\text { Bicycle park- } \\
\text { ing }\end{array}$ & \\
\hline MM & Park \& ride & Transport on re- & Carpooling/ & Urban tolls & \\
\hline
\end{tabular}




\begin{tabular}{|c|c|c|c|c|c|}
\hline & & quest & Carsharing & & \\
\hline MIP & Road accessibility & $\begin{array}{l}\text { Adapted PT stops } \\
\text { and vehicles }\end{array}$ & & & \\
\hline UF & $\begin{array}{l}\text { Traffic control for } \\
\text { heavy vehicles }\end{array}$ & Limited timetables & Transport Centres & & \\
\hline MLU & Pedestrian zones & $\begin{array}{l}\text { Integrated public } \\
\text { transport/urban } \\
\text { planning }\end{array}$ & $\begin{array}{l}\text { City and neighbour- } \\
\text { hood friendly design }\end{array}$ & & \\
\hline EQ/ES & $\begin{array}{l}\text { Fleets: electrical, gas, } \\
\text { bio diesel; } Z B E\end{array}$ & $\begin{array}{l}\text { Tax incentives for } \\
\text { buying or renewal }\end{array}$ & $\begin{array}{l}\text { Cycle lanes and pe- } \\
\text { destrian itineraries }\end{array}$ & & \\
\hline MPC & Placement & $\begin{array}{l}\text { Company buses } \\
\text { (shuttle/routes) }\end{array}$ & $\begin{array}{c}\text { Specific PT lines; } \\
\text { cycles parking; cycling } \\
\text { facilities }(\text { showers, } \\
\text { lockers, etc.) }\end{array}$ & $\begin{array}{l}\text {-Tele work- } \\
\text { ing } \\
\text {-Flexible or } \\
\text { compressed } \\
\text { timetable }\end{array}$ & $\begin{array}{c}\text { Company trans- } \\
\text { port season ticket }\end{array}$ \\
\hline SI & $\begin{array}{l}\text { Roadsigns improve- } \\
\text { ment }\end{array}$ & $\begin{array}{l}\text { Junctions im- } \\
\text { provement }\end{array}$ & $\begin{array}{l}\text { Flows division: one } \\
\text { space for mode }\end{array}$ & & \\
\hline
\end{tabular}

Table 1. Possible measures of a Sustainable Urban Mobility Plans. Source: Own, from Guía práctica para la elaboración e implementación de PMUS.

The lack of space prevents this paper from showing the analysis of cases which would result on a more detailed benchmarking exercise. So, let's say that each country has developed its legislation, rules or guidelines having in mind the different needs of their municipalities. The monitoring process carried out by and in each one of them, shows different results against the specified objectives of the plan.

\begin{tabular}{|c|c|c|c|c|c|}
\hline City & Population & Main objectives & Measures & Funding & Monitoring \\
\hline $\begin{array}{l}\text { Lille } \\
\text { Metropole ( FR) } \\
\text { Scheme: PDU }\end{array}$ & $\begin{array}{l}1,2 \text { million } \\
87 \text { communes }\end{array}$ & $\begin{array}{l}\text { Double PT } \\
\text { use2000/2015 }\end{array}$ & $\begin{array}{l}\text { Increase PT offer } \\
\text { and network, inter- } \\
\text { changes }\end{array}$ & $\begin{array}{l}\text { Communauté } \\
\text { urbain, region, } \\
\text { department, UE }\end{array}$ & $\begin{array}{l}-P T \text { increased } 30 \% \\
98 / 06) \\
\text {-Private car reduce }\end{array}$ \\
\hline $\begin{array}{l}\text { Darlington (UK) } \\
\text { Scheme: LTP }\end{array}$ & 100,000 & $\begin{array}{l}\text { Accesibility, } \\
\text { congestion, air } \\
\text { quality }(00 / 06)\end{array}$ & $\begin{array}{l}\text { Integrated transport } \\
(P T, \text { cycles, pedes- } \\
\text { trian }), \text { road safety; } \\
\text { maintenance }\end{array}$ & $\begin{array}{l}£ 3,062(05 / 06) \\
\text { (National, re- } \\
\text { gional, local) }\end{array}$ & On track \\
\hline Burgos (SP) & 160,000 & $\begin{array}{lr}\text { Reduce } & \text { emis- } \\
\text { sions, } & \text { PT, re- } \\
\text { cover } & \text { public } \\
\text { space } & \\
(05 / 09) & \\
\end{array}$ & $\begin{array}{l}\text { Restricted access, } \\
\text { parking strategy, } P T \\
\text { improvement, bio- } \\
\text { diesel, public bike } \\
\text { scheme }\end{array}$ & $\begin{array}{l}\text { UE (Civitas), } \\
\text { municipality, re- } \\
\text { gion }\end{array}$ & $\begin{array}{l}\text { 90\%pedest., } \\
\text { 100\%public fleet bio- } \\
\text { diesel, increase num- } \\
\text { ber of cyclists, } 3 \text { off- } \\
\text { street parking, PT= }\end{array}$ \\
\hline $\begin{array}{l}\text { Genoa (IT) } \\
\text { Scheme: PUM }\end{array}$ & $622,000(M A)$ & $\begin{array}{l}\text { PT, reduce pol- } \\
\text { lution, renew- } \\
\text { able, reduce } \\
\text { traffic in city } \\
\text { centre, road } \\
\text { safety }\end{array}$ & $\begin{array}{l}\text { Access control, ur- } \\
\text { ban toll, collective } \\
\text { taxis, parking infor- } \\
\text { mation, PT clean ve- } \\
\text { hicles }\end{array}$ & $\begin{array}{lr}U E \quad \text { (Civitas), } \\
\begin{array}{l}\text { national, } \\
\text { gion, }\end{array} \\
\text { pality, }\end{array}$ & $\begin{array}{l}\text { Increase renewable } \\
17 \%(P T), \text { increase } P T \\
\text { users, less traffic in the } \\
\text { centre, increase pedes- } \\
\text { trian areas }\end{array}$ \\
\hline
\end{tabular}




\begin{tabular}{|c|c|c|c|c|c|}
\hline $\begin{array}{l}\text { Grenoble Campus } \\
\text { (FR) } \\
\text { Scheme: MicroPDU } \\
(07)\end{array}$ & $\begin{array}{l}\text { Universities } \\
\text { area }(50,000 \\
\text { students })\end{array}$ & $\begin{array}{lr}\text { Foster } & \text { soft } \\
\text { modes, reduce } \\
\text { private rar } \\
(40 \%) \text { and park- } \\
\text { ing space }\end{array}$ & $\begin{array}{l}\text { Tramway enlarge- } \\
\text { ment, bike parking } \\
\text { and lanes, improve } \\
\text { accessibility soft } \\
\text { modes, car pooling }\end{array}$ & $P D U$ & On track \\
\hline $\begin{array}{l}\text { Apeldoorn (NL) } \\
\text { Scheme: Traffic and } \\
\text { Transport Plan } \\
(99 / 10)\end{array}$ & 156,000 & $\begin{array}{l}\text { Access to city } \\
\text { centre, bicycles, } \\
\text { Mobility plans } \\
\text { for big areas }\end{array}$ & $\begin{array}{l}\text { Pedestr, bikes prior- } \\
\text { ity, areas 30, park- } \\
\text { ing information, } \\
P T+P \& R, \quad \text { special } \\
\text { buses for schools, } \\
\text { hospitals and indus- } \\
\text { trial areas }\end{array}$ & $\begin{array}{l}\text { Municipality } \\
\text { province and } \\
\text { public and pri- } \\
\text { vate institutions }\end{array}$ & $\begin{array}{l}\text { Accidents decrease } \\
50 \% \text { (99/04), road } \\
\text { congestion improved } \\
\text { (citizen satisfaction in- } \\
\text { dex increased from } 7 \text { to } \\
8)\end{array}$ \\
\hline $\begin{array}{l}\text { Aalborg } \\
\text { Traffic/Environment } \\
\text { Action Plan (1994-) }\end{array}$ & 192,000 & $\begin{array}{l}\text { Reduce traffic, } \\
\text { energy consump- } \\
\text { tion, emissions }\end{array}$ & $\begin{array}{l}\text { Parking manage- } \\
\text { ment, bus priority, } \\
\text { company bikes, car } \\
\text { sharing }\end{array}$ & $\begin{array}{l}\text { Municipality, } \\
\text { national gov. }\end{array}$ & On track ${ }^{2}$ \\
\hline
\end{tabular}

Table 2. Measures of a Sustainable Urban Mobility Plan. Source: Own

It is important to remark that, despite the long list of cities analysed, only a few provide data regarding the quantitative reduction of emissions. Almost all of the plans give information about the impact of the measures on congestion and modal shift, which obviously have positive effects on urban environment, but it is not enough since detailed consideration of local circumstances should be needed.

\section{Results and discussion}

As it can be seen, each country names its urban mobility plans in a different manner: PDUs, PTUS, PUM, LTP are all different names given to the same reality. But, as "head document" above all of them the UE is remarkable the recent Green Paper Towards a new culture for urban mobility (COM 2007), that claims for integrated urban mobility approaches, expressed in Sustainable Urban Transport Plans (SUTP). This document

\footnotetext{
${ }^{2}$ Ad exemplum: regarding environmental and energy impacts of the parking system information, calculations of energy reductions were made on the basis of an average speed of $30 \mathrm{~km} / \mathrm{h}$. All 'searching' traffic is car. $20 \%$ of all cars are equipped with catalytic exhaust purifiers. Based on this the reduction in energy consumption will be $3521 \mathrm{MJ}$ or 9711 of petrol daily. On an annual basis this is $980,000 \mathrm{MJ}$ or 29,400 1 of petrol.

The equivalent reductions in emissions on an annual basis are: $\mathrm{CO} 2: 7$ ton, Nox: 0.5 ton, $\mathrm{CO}: 7.7$ ton, $\mathrm{HC}: 0.57$ ton, particles $5 \mathrm{~kg}$. This reduction equals approximately $0.3 \%$ of the total annual emissions from traffic in Aalborg City.
} 
proves that it is time to act and ${ }^{3}$, so, the European Commission committed itself to produce guidelines to implement those plans, not yet published. These guidelines should be the umbrella to cover the different national plans, suggesting a minimum content for each one in such a way that all of them had a common evaluation framework, with a set of indicators and goals that allowed, through a benchmarking exercise, the dissemination of good practices. Anyway, it is indifferent the use of the term "transport" or "mobility" as long as the plan reflects the concept of mobility regarding objectives, policies and measures (Expert Working Group on SUTP, Ruprecht Consult, 2004)

On the other hand, being true that there is nothing new under the sun, we could ask then which could be the added value of the EU initiative derived from the Green Paper. The answer adopts different forms: promoting the exchange of good practices at all levels (local, regional and national); underpinning the establishment of common standards and the harmonisation of standards if necessary; offering financial support to those who are in greatest need of such support; encouraging research the applications of which will make it possible to bring about improvements in mobility safety and environmental; simplifying legislation and, in some cases, repealing existing legislation or adopting new legislation. Not certainly minor questions to put into practice, although none of them are a big novelty.

The cases analysed in this paper show that regardless the existence or not of a specific law, and the different names adopted, there are some countries where successful urban mobility plans have been implemented. In Spain, for instance, these plans are not compulsory, but there are many municipalities that have started to implement them benefiting from the national subsidies, what is, at last, the main problem: funding.

And, just regarding on funding schemes, is very important to link it to the achievement of the objectives (as in the UK). And closely related to this we must remark the importance of a good set of key, homogeneous, available and clear indicators that allow to calculate the effectiveness and level of achievement of the measures implemented which, in turn, will allow to design alternatives, becoming a key support of the decision making process.

Another important aspect is the need of coordination between the different levels of the administration, both hierarchical and horizontal, i.e, National Government/ Region/Department/Local, and between departments of the same administration, beyond informal cooperation agreement. The

\footnotetext{
3 Indeed, if in 2001 the White Paper European Transport Policy first came out under the title "time to decide", maybe this Green one should be called as "time to act".
} 
coordination is especially visible in France and the UK, where the urban plans must be coherent and consistent with the national and regional land use planning, and with the air quality legislation. In the second case (UK), integration with sectoral policies (disabled, social inclusion, noise) is required as well.

Plans must be realistic, since in some cases seems obvious that the objectives are clearly Utopian, as public institutions seems more interested in "sell" it than in implement it (at last, are the citizens who vote). Sometimes, in fact, results may be better acting on a small area, such as universities, whose mobility is half a commuter plan and half an urban mobility plan.

Finally, it is highly recommended to avoid the temptation brought about by the language tricks: pompous names do not turn into better what is not and, all in all, it is the same a Sustainable Urban Mobility Plan that a Local Development Strategy... as long as it is sustainable, of course.

\section{REFERENCES}

[1] EUROPEAN ENVIRONMENT AGENCY. TERM 2007: Indicators tracking transport and environment in the European Union (Report 1/2008).

[2] EUROPEAN COMMISSION White Paper European Transport Policy for 2010: time to decide (COM (2001) 370 final).

[3] INFRAS-IWW. External costs of transport. October 2004.

[4] EUROPEAN COMMISSION. Green Paper: Towards a new culture for urban mobility COM (2007) 551.

[5] EUROPEAN COMMISSION. Communication from the Commission to the Council and the European Parliament on Thematic Strategy on the Urban Environment. SEC (2006) 16.

[6] Loi d'Orientation des Transports Intérieurs (LOTI), 1982; Loi sur l'Air et l'Utilisation Rationnelle de l'Energie (LAURE) 1998; Loi Solidarité et Renouvellement Urbain (SRU), 2000.

[7] CENTRE D'ETUDES SUR LES RESEAUX, LES TRANSPORTS, L'URBANISME ET LES CONSTRUCTIONS PUBLIQUES (CERTU). Les Plans de déplacements Urbains. Guide Méthodologique. 1996.

[8] THEVENON, JEAN (CERTU) "The urban travel plan in France: 25 years on. From UTP to SUTP?" IDAE, Espacios Urbanos Espacios Humanos...hacia una movilidad sostenible", Madrid, March 14-15, 2007.

[9] THOMÉ, BENOÎT, Local public transport organisation in France: A new deal? Seventh THREDBO Conference, Molde (Norway) - June 2001.

[10] DEPARTMENT FOR TRANSPORT (DfT) Full Guidance on Local Transport Plans (on line). Second Edition. Draft for consultation. London, DfT 2004. 
[11] MINISTERIO DE MEDIOAMBIENTE. Planes de Movilidad Urbana. Tecnologías de Reducción de Emisiones en el Transporte. Madrid, 21-22 September 2005.

[12] EXPERT GROUP IN GROUP ON SUSTAINABLE URBAN TRANSPORT PLANS. Final Report 17 December 2004.

[13] INSTITUTO PARA LA DIVERSIFICACIÓN Y EL AHORRO DE ENERGÍA. Guía práctica para la elaboración e implementación de Planes de Movilidad Urbana Sostenible, IDAE, Madrid, 2006.

[14] SUSTAINABLE URBAN TRANSPORT PLANS AND URBAN ENVIRONMENT: Policies, effects and simulations. Final Report, 10 October 2005. 